\title{
Anti-corruption audit as an imperative of effective environmental management
}

\author{
Karina Nazarova ${ }^{1}$, Mariia Nezhyva $^{1}$, Volodymyr Hordopolov ${ }^{1}$, and Viktoriia Mysiuk ${ }^{1}$ \\ ${ }^{1}$ Kyiv National University of Trade and Economics, Financial Analysis And Audit Department, 19, \\ Kyoto str., 02156 Kyiv, Ukraine
}

\begin{abstract}
In order for the global society to emerge from the socioeconomic COVID crisis, as well as to reduce its high level of eco-anxiety of various etymologies, it is necessary to restore public confidence in effective management of key segments of the national economy as an imperative of national security. In the Transparency International-19 Corruption Perceptions Index, Ukraine ranked 129th out of 180 countries (with an index of 30). The way out of the permanent state of eco-anxiety is possible only if the public information space is filled with well-founded messages about overcoming corruption risks, which are aimed at effective anti-corruption audit, which should be based on the results of basic research. The development of the region is not possible without ensuring the stable functioning of all its components: the population of the region, the state of entrepreneurship. In this case, each of the parts of the system is in correlation with each other. That is why the first direction of regional policy should be to support the introduction of eco-management in enterprises, as well as the formation of environmental behavior in the population of the region. Anti-corruption audit is an imperative for effective environmental management.
\end{abstract}

\section{Background}

The key problem at the global and national levels, which manifested itself globally in 2020, is the rapid growth of eco-anxiety on the planet. The COVID crisis is a manifestation of the global financial and economic, environmental, social and political crisis and is a serious challenge for the world in general and Ukraine in particular. Non-compliance with environmental obligations, conflict of interest and conflict between the provisions of different acts of equal legal force in resolving the same issue, which allows for different interpretations of norms and requirements, creates a basis for abuse. This problem can be solved by implementing institutional measures of anti-corruption audit, which will help to overcome the eco-anxiety of society and effectively combat corruption and abuse.

The fight against corruption, control of compliance with anti-corruption legislation, implementation of anti-corruption measures in public authorities, local governments and the activities of economic entities have always been the prerogative of the state. The turbulence of the economic environment and the COVID crisis are currently exacerbating threats to

\footnotetext{
* Corresponding author: marijka@ukr.net
} 
national security and emphasizing the importance of government intervention. Conducting an effective and efficient anti-corruption audit in order to minimize the eco-anxiety of society requires justification and establishment of clear criteria for expanding the range of entities that will be subject to anti-corruption audit in Ukraine and, accordingly, determining anti-corruption audit. Implementation of anti-corruption audit in overcoming the eco-anxiety of society is impossible without the formation of methodological tools for its implementation.

The constantly growing trend to increase the amount of information that needs to be processed both within an individual economic entity and within the country as a whole, leads to the formation of innovative approaches to ensure the effective implementation of business processes. It is the dynamic change of approaches to building and conducting business, which is due to the expansion of opportunities to take advantage of the open economy, has sharply raised the issue of transition to digitalization of economic processes in the country. In turn, this form of business process support requires prompt adaptation of the country's anti-corruption system, which is designed to prevent and counter the formation of innovative corruption schemes, given the use of legally unprotected tools for digitalization of business processes. Today, the fight against corporate fraud is an important condition for economic stability of both businesses and the state. In practice, only some economic crimes are solved, while others remain in the shadows. With this in mind, more than 190 domestic companies have joined the UN Global Compact, according to which companies seek to create and maintain an ethical framework of corporate culture at both operational and strategic levels.

The term "management" is widely used in relation to various socio-economic processes occurring in the objects of economic activity in modern market conditions. Special forms of management have become widespread, focused on certain functional areas of activity of organizations and enterprises: financial management, personnel management, innovation management, quality management, etc. Environmental management is also gradually developing. Environmental management is a part of the general management system, which includes the organizational structure, planning activities, division of responsibilities, practical work, procedures, processes and resources for development, implementation, achievement of goals, evaluation of environmental policy. Environmental management is focused on regulating the interaction of society and the environment.

Increased attention from regulators to the prosecution of violators has made the fight against bribery and corruption highlighted in companies operating internationally, including Ukraine. However, according to a study by EY Global Limited, as of 2019, Ukraine ranks first in terms of corruption and fraud. In addition, in the International Corruption Perceptions Index, Ukraine ranks 130th and is rightly considered a country at high risk of corruption.

The development of the region is not possible without ensuring the stable functioning of all its components: the population of the region (its state of health, welfare, demographic situation, etc.), the state of entrepreneurship (profitability, number of jobs created, etc.). In this case, each of the parts of the system is in correlation with each other. That is why the first direction of regional policy should be to support the introduction of eco-management in enterprises, as well as the formation of environmental behavior in the population of the region. Anti-corruption audit is an imperative for effective environmental management.

\section{Analysis of recent researches and publications}

The issue of anti-corruption policy is the subject of research by scientists: K. Ayub [1], N. Babyak [2], L. Gnylytska [3], M. Grishchuk [4], O. Dyka [5], Yu. Zarembsky [6], A. Marchenko [7], K. Naumchuk [8], O. Parkhomenko-Kutsevil [9], K. Rostovska [10], 
A. Sobakar [11], S. Timofeev [12], Y. Fidrya [13], L. Chizhevskaya [14], M. Shcherbak [15], Y. Mizik [16], A. Fadeeva [17], Yu. Slobodyanyk [18], D. Shkarovsky [19], K. Nazarova [20-23] and others. Analysis of the state and degree of scientific developments in foreign and domestic sources on the studied issues shows that corruption is not only a crime against the state and the citizen Y. Mizik [16], A. Fadeeva [17], O. ParkhomenkoKutsevil [24], but also affects development of the system of subjects in the field of prevention and counteraction of corruption, which threatens the perception of legitimate actions of state bodies and security of citizens, negatively affects the reputation of public authorities, hinders the reform of the public administration system. At the same time, taking into account the work of P. Nieuwlands [25], J. Tillipman [26] the study will identify new trends and patterns of corruption in the system of public authorities at the local level and develop approaches to improve mechanisms to prevent and combat corruption in local government in Ukraine. Particular emphasis will be placed on the analysis of modern anticorruption institutions as a basis for preventing and overcoming corruption, primarily in the public sector of the economy Yu. Slobodyanyk [18], B. Golovkina [27] the formation of innovative ways to develop anti-corruption institutions in Ukraine. Anti-corruption audit is relatively new to national science and practice. However, today there are a number of publications related to this issue. In the article L. Gnilitskiy [28] reveals the differences between business audit and anti-corruption audit, as well as outlines the tasks and methods of anti-corruption audit. A. Fadeeva [29] emphasize the importance of anti-corruption audit for the effective development of both individual organizations and the state as a whole. A. Novikov [30] reveals the essence of the introduction of anti-corruption compliance in the activities of domestic companies as one of the mechanisms to prevent corruption. Scientists of the Department of Financial Analysis and Audit of the Kyiv National University of Trade and Economics studied the protection of business through the sights of anti-corruption audit. Scientific research on this problem has established that the method of conducting anti-corruption audit is not fully disclosed and requires new research.

B. Bui [31] explore that accounting technologies can be used to help incentive packages achieve the dual goals of economic incentives and climate mitigation. Using the perspective of institutional logic, despite the significant financial implications of climate change, the current climate response is dominated by economic logic that justifies limited action. Further, despite the great potential, accounting technologies are not widely used in the development of incentive packages. It develops the framework for the clear integration of accounting technologies into the development, delivery and revision of incentive packages, thus ensuring economic growth and social justice while addressing the climate crisis. $\mathrm{Yu}$. Vertakova [32] presents the results of the analysis of the economic, environmental and social development of the countries of the world in the modern period in conjunction with measures of state regulation, aimed at eliminating the negative impact of the development of the economic system on the environment and implementation sustainable development concept. N. Mohring [33] notes that the reduction of adverse health and environmental effects from pesticide use is currently a top priority on the agricultural policy agenda. Efficient pesticide policies must take into account farmers' application behavior, especially effects of pesticide use on economic risk. Farmers will ceteris paribus use lower quantities of herbicides, but will increase the overall toxicity of the products applied with increasing risk aversion. V. Pavlyk [34] analysis of the green investment impact on the energy efficiency gap. A. Shkuropat [35] proposes to incorporate the main indicators of "green" growth into national and regional blocks of multi-regional models, starting with the simplest options such as small econometric models of partial equilibrium, into which based on a specially conducted analysis - the most significant factors of sustainable economic growth and exogenous parameters of public policy are included. 
A special place is given to testing the effectiveness of "green" economy measures. O. Karpenko [36] introduction of the green economy model in the mechanism of state policy, development of state and regional institutions of management, transformation of social relations and modification of administrative management with saturation of its ecological dominant and development of measures on priority definition of their segments of environmentalization of national development. V. Potapenko [37] notes that green modernization of economy through analysis of barriers and drivers based on interviewing of the companies.

The purpose of the article is to determine the tasks of anti-corruption audit, features and problems of its conduct, as well as methodological directions of its conduct.

\section{Materials and methods}

The materials of the research were scientific works of foreign and domestic scientists on anti-corruption audit, data of the global rating of Ukraine among the countries of the world for the level of corruption, as well as statistical data on the activities of Ukrainian enterprises. The research was conducted using both general scientific methods of cognition of economic phenomena and processes, and special research methods, in particular, analysis, synthesis, systematization, theoretical generalization and comparison, statistical analysis, structural analysis, methods of expert evaluation and forecasting.

The research was conducted using the following methods: monographic - to generalize the theoretical and methodological foundations of anti-corruption audit as an imperative for effective environmental management; analysis and synthesis, induction and deduction problem delivery, detailing and clarification of the subject of research; system analysis - to clarify the essence of the concepts of "anti-corruption audit", "imperatives", "environmental management efficiency"; graphic - for visual and schematic representation of theoretical and practical research results. The information base of the study is monographic literature, regulations of Ukraine, materials of periodicals, as well as information from the Internet.

\section{Results}

Corporate fraud detection studies in Ukraine indicate a trend toward growth. According to the report by PwC, World Economic Crime and Fraud Survey 2019: Survey of Ukrainian organizations, it turns out that bribery and corruption are the most common types of corporate fraud ( $23 \%$ of respondents). At the same time, the level of bribery and corruption in their own companies increased from $56 \%$ of respondents in 2016 to $73 \%$ in 2019 . Thus, according to analysts, the level of corruption faced by business is currently growing [38]. The National Agency for Corruption's supervision of fraud in 2018 revealed 471 administrative offenses and brought them to court (Fig. 1) [39].

In the modern literature, researchers consider anti-corruption audit as a component of fraud audit, along with the facts of accounting for fraud and asset theft. Anti-corruption audit should be understood as a system of measures to manage the risks of non-compliance with the legislation of Ukraine and other countries, other normative documents, standards and ethical norms related to the fight against corruption.

Corporate anti-corruption auditing is an effective tool for combating corruption and corporate fraud. It helps to reduce the negative trends caused by the actions of company officials related to abuse of power. 


\section{THE NUMBER OF ADMINISTRATAVE RECORDS SENT TO} COURT IN 2018
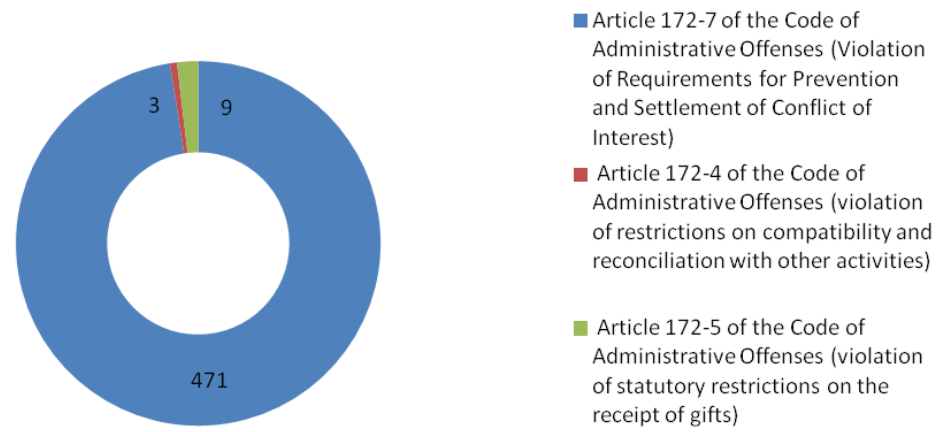

Fig. 1. Number of fraudulent administrative reports sent by the National Anti-Corruption Agency in 2018 .

The peculiarity of conducting the anti-corruption audit is to evaluate the presence and observance of the company anti-corruption policy, which promotes transparency, investment attractiveness of the company and prevention of penalties.

The Law of Ukraine "On Prevention of Corruption" [40] provides for the procedure of approval of the anti-corruption program and requirements for its provisions, which are formed taking into account the assessment of corruption risks.

According to studies of modern management practices of most domestic enterprises, a serious problem faced by their management in conducting anti-corruption audit is the lack of organizational and legal support for such activities at the legislative level, random nature of existing methodological developments on the use of audit technologies, analysis of anticorruption technologies and analysis the lack of an adaptive system for training such specialists in domestic educational institutions to the requirements of the relevant services market [41]. The main directions of anti-corruption audit are shown in Fig. 2.

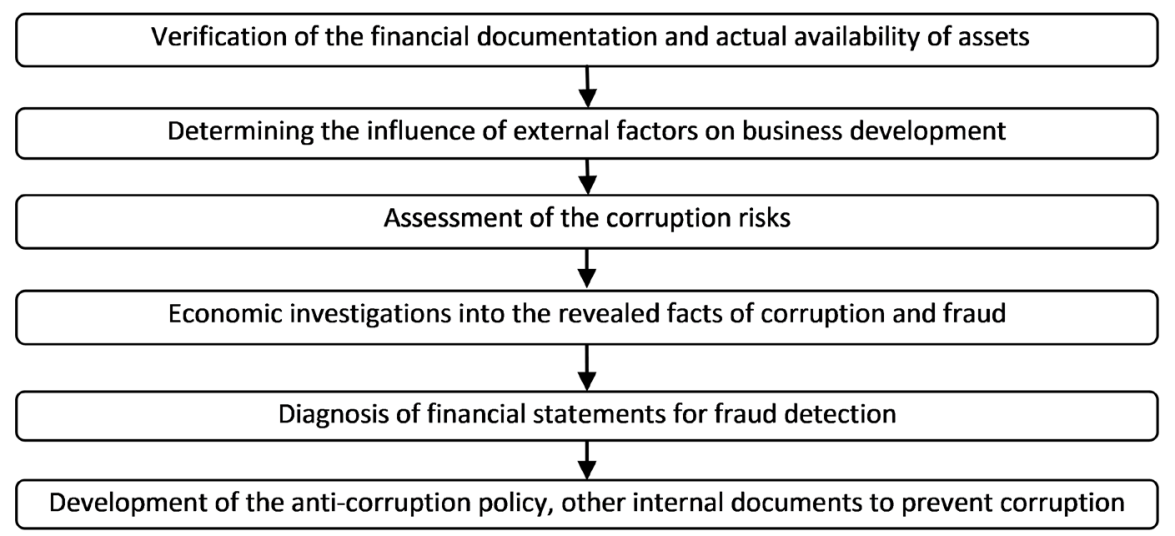

Fig. 2. Imperative directions of the anti-corruption audit.

One of the areas of anti-corruption audit is the assessment of corruption risks in the activities of a legal entity. According to the decision of the National Agency for the Prevention of Corruption [42], a legal entity must undergo an external evaluation of an audit, legal or consulting company at least once every three years. 
There are many ways to misstate financial statements. The main ones include falsification of original documents, fictitious accounting records, narrowing of assets and liabilities, consolidation of heterogeneous amounts in one article reporting payments through shell companies, etc. Domestic companies may also include: fraudulent actions with company documents (forgery or falsification of documents); creation of controlled entities and receipt of operations; artificially high prices; conspiracy agreements (suppliers, customers) and false documentation, application of the "kickback" system; create accounts for outstanding works (services); the presence of atypical economic transactions and transactions at the end of the year that affect the financial results (capital, assets and liabilities) of the company; use of the company's assets for personal purposes, etc.

During the anti-corruption audit, it is advisable to take into account a possible conspiracy between the company's management and the accounting department. Owners often manipulate the company's financial results to maximize revenue, improve the company's investment attractiveness, or comply with the terms of contracts with third parties. Therefore, to identify elements of corruption, it is very important to use techniques and methods that can reveal the involvement of management in corruption crimes by distorting financial statements.

External auditors in assessing the risk of fraud can be identified by certain criteria, namely: if the company has a developed or illogical organizational structure, there is a high turnover of staff, including management staff and directors. Auditors can also warn about risky transactions carried out by the company and that they may bring significant profits in the future. Corruption schemes also include the following operations: incomplete accounting of inventory; unjustified write-off of cargo and material values for excessive losses during storage, transportation, natural disasters, etc.; disclosure of trade secrets for financial reward; payment for unprovided services or lag (services); payment of wages to employees who do not work at the enterprise, etc.

Today, an important way to fight corruption is to implement cybersecurity mechanisms. According to Allianz and WEF, cyber risks rank 2nd among all business threats and are among the top 10 risks of mankind. According to the FBI's Internet Crime Complaints Center, the damage caused by cybercrime in the world over the past five years has been $\$$ 12 trillion. The study found that the most common types of crime faced by a company are misappropriation of property $(46 \%)$, procurement fraud $(33 \%)$ and personnel management $(33 \%)$, and cybercrime $(31 \%)$. Six thousand crimes were detected in the field of high information technology in Ukraine in 2018 [43].

The information space has become a place and an instrument of crimes, because now a crime can be committed with the help of information and communication systems. When implementing an anti-corruption audit, auditors should evaluate the experience and integrity of the company's senior management by conducting interviews, checking awareness of the company's corporate culture. During the audit, they work on the analysis of the structure of corporate business, the structure of corporate governance and corporate security, as well as study the external environment of the enterprise, the possibility of political and criminal influence. The risk map, organizational and administrative documentation, competitive environment are also analyzed.

When conducting an anti-corruption audit, it is advisable to use appropriate software, such as the software-analytical complex Global Security Assessment. An external audit of a company's corporate security eliminates or significantly minimizes the negative risks faced by most companies, which even have their own security service. It should be noted that auditors who are required to conduct anti-corruption audits must be familiar with both national and foreign legislation to prevent and combat corruption.

The specificity of environmental management is that this system is engaged in planning and regulating the conscious human impact on the environment to meet their own economic 
needs in terms of sustainable development of society. The separation of environmental management as an independent science has led to qualitative changes, as environmental management applies to all three named types of systems: physical, physical, biological, biological and social. Environmental management is part of the overall system of corporate governance and aims to implement the objectives of environmental policy in the field of environmental protection. Its concept is based on the model of sustainable development, which provides for a harmonious relationship between socio-economic development and the environment without harming future generations. One-sided orientation of economic activity to achieve economic results without taking into account environmental and environmental requirements cannot ensure sustainable development of society. Environmental policy of the enterprise provides: determining the activities of the organization, setting the parameters of production activities, setting environmental objectives, determining the criteria for assessing the environmental efficiency of environmental efficiency, reduction of environmental risks and reducing the cost of material resources.

The need for environmental management is determined not only by the deterioration of the eco-state, the environmental crisis, but also the natural trends of modern production, such as: differentiation of regional location of production, growth of production capacity in accordance with new technologies, the division of countries in world economy economies on those who produce toxic poisonous waste and those who concentrate it concentrate. The introduction of environmental management is also conditioned by the trends of scientific and technological progress (biotechnology, biotechnology, nuclear technology) and the emergence of environmental ecological consciousness of consciousness.

Environmental management is one of the areas of modern management and develops on its theoretical and methodological principles. It is the science of management formulates the main basic approaches to the creation of linear and functional organizations in environmental management, centralization of centralization and decentralization of management decentralization, organization of interaction and motivational processes, delegation of authority, organization of management work.

Leading environmental managers agree that by increasing the level of environmental safety of production and consumption, resource conservation and minimization of environmental risks, environmental management allows companies: to find new opportunities to save material costs, to master new environmental markets, increase the competitiveness of products; regions and countries - to improve the quality of the environment, taking into account the interests of present and future generations; nature itself - to support biodiversity and the richness of natural resources. The peculiarity of environmental management is the fact that it involves the development of environmental tasks on the basis of appropriate strategies, programs, their implementation by creating specialized structures, control over the results at all levels. First of all, this is due to the fact that environmental problems are long-term and global in nature and affect the interests of different generations. Accordingly, we propose to divide the levels of implementation and implementation of eco-management into: state, regional and local (Fig. 3). Tasks for each level of eco-management differ in their importance and implementation of functions (planning, organization, control and motivation).

The key tasks and result of environmental management today is the creation of legal, economic and social foundations for its implementation at each of the levels considered (Fig. 4). 


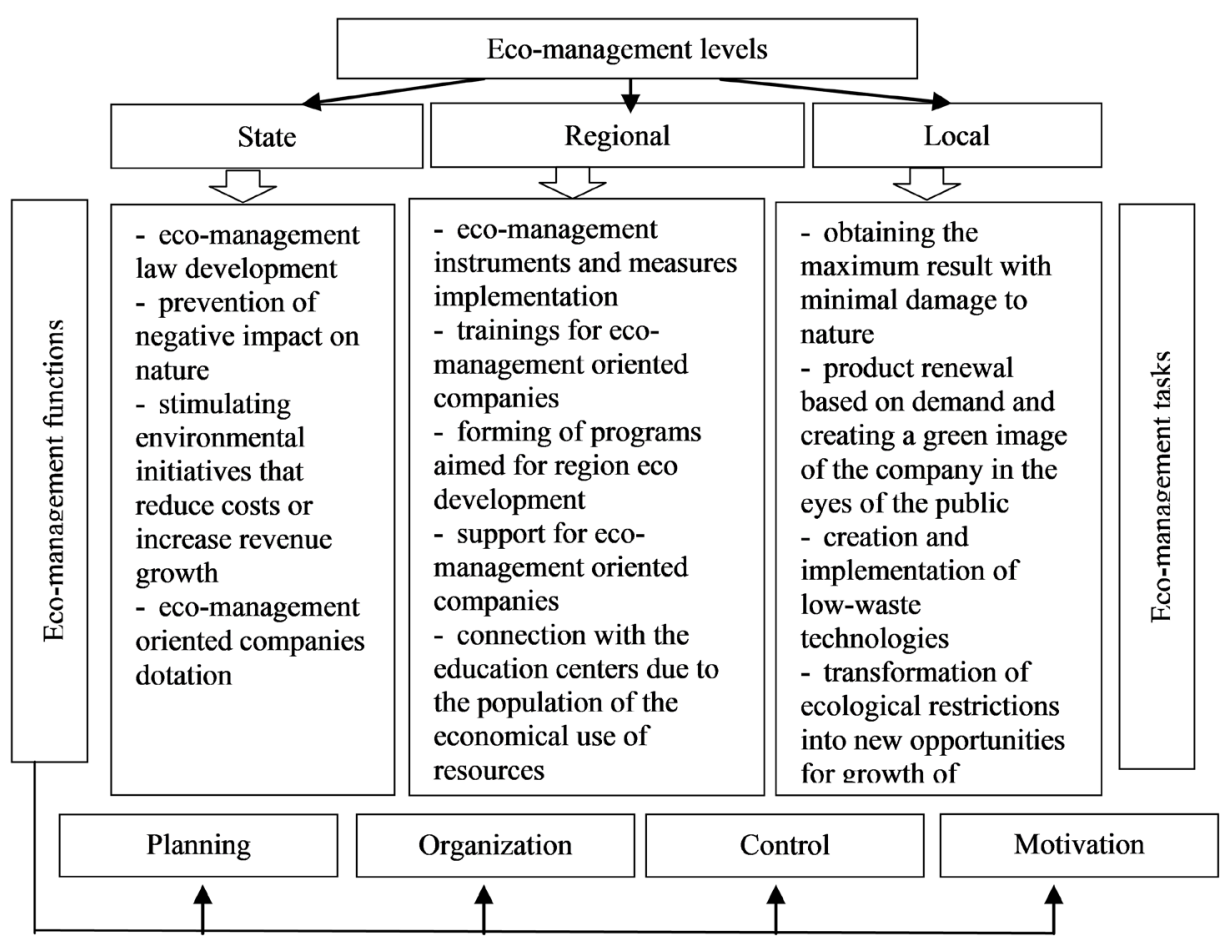

Fig. 3. Eco-management levels.

\begin{tabular}{|c|c|c|c|c|}
\hline Eco-management & & & Eco-management & \\
\hline State & Regional & Society & Company & \\
\hline 5 & L & L & 25 & \\
\hline $\begin{array}{l}\text { 1. Standards } \\
\text { development } \\
\text { 2. Self } \\
\text { management laws } \\
\text { development } \\
\text { 3. Establishing } \\
\text { administrative } \\
\text { liability for non- } \\
\text { compliance } \\
\text { 4. Improving the } \\
\text { health of the }\end{array}$ & $\begin{array}{l}\text { 1. Including to } \\
\text { Complex } \\
\text { programs region } \\
\text { development eco } \\
\text { part } \\
\text { 2. Stimulating } \\
\text { entrepreneurs to } \\
\text { environmental } \\
\text { behavior } \\
\text { 3. Companies } \\
\text { dotation }\end{array}$ & $\begin{array}{l}\text { 1. Frugal } \\
\text { behavior with } \\
\text { resources } \\
\text { 2. Waste sorting } \\
\text { 3. Reducing the } \\
\text { level of unused } \\
\text { waste } \\
4 . \text { Formation of } \\
\text { eco- } \\
\text { consciousness }\end{array}$ & $\begin{array}{l}\text { 1. Introduction } \\
\text { of energy } \\
\text { efficient } \\
\text { technologies } \\
2 \text {. Ensuring } \\
\text { waste-free } \\
\text { production } \\
\text { 3. Waste } \\
\text { processing } \\
\text { 4. Product } \\
\text { labeling rules }\end{array}$ & 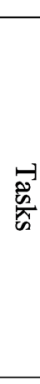 \\
\hline $\begin{array}{l}\text { 1. Eco- } \\
\text { environment } \\
\text { 2. Saving } \\
\text { resources } \\
\text { 3. Budget income }\end{array}$ & $\begin{array}{l}\text { 1. Eco-company } \\
\text { 2. Eco-resources } \\
\text { 3. Eco-region } \\
\text { 4. Pollution } \\
\text { reduction }\end{array}$ & $\begin{array}{l}\text { 1. Eco-thinking } \\
\text { 2. Ratio- } \\
\text { consumption } \\
\text { 3. Eco- } \\
\text { communication }\end{array}$ & $\begin{array}{l}\text { 1. Eco-Product } \\
\text { 2. Eco- } \\
\text { Producing } \\
\text { 3. Eco- } \\
\text { Management }\end{array}$ & 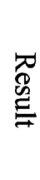 \\
\hline
\end{tabular}

Fig. 4. Eco-management tasks. 
The Environmental Efficiency Index [44] allows countries to be ranked in several categories, which are grouped into two groups: ecosystem viability and environmental health. Ukraine ranked 44th in 2016, improving its results by $25 \%$ in 10 years and found itself between Argentina - 43 and Cuba - 45 (Fig. 5).

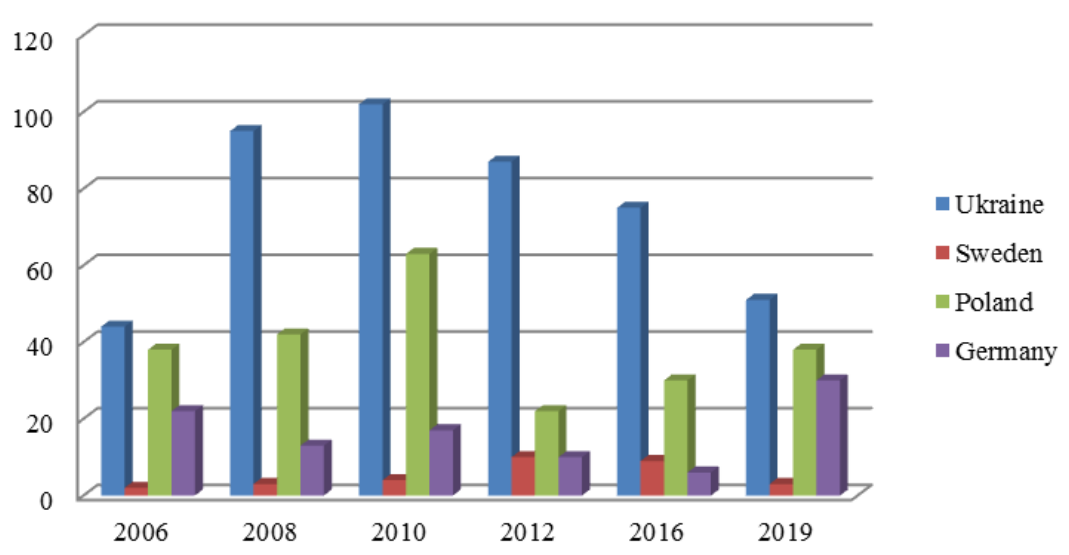

Fig. 5. Rating of Ukraine in the Environmental Efficiency Index for 2006-2019.

Enterprises need to develop the following environmental areas (Fig. 6).

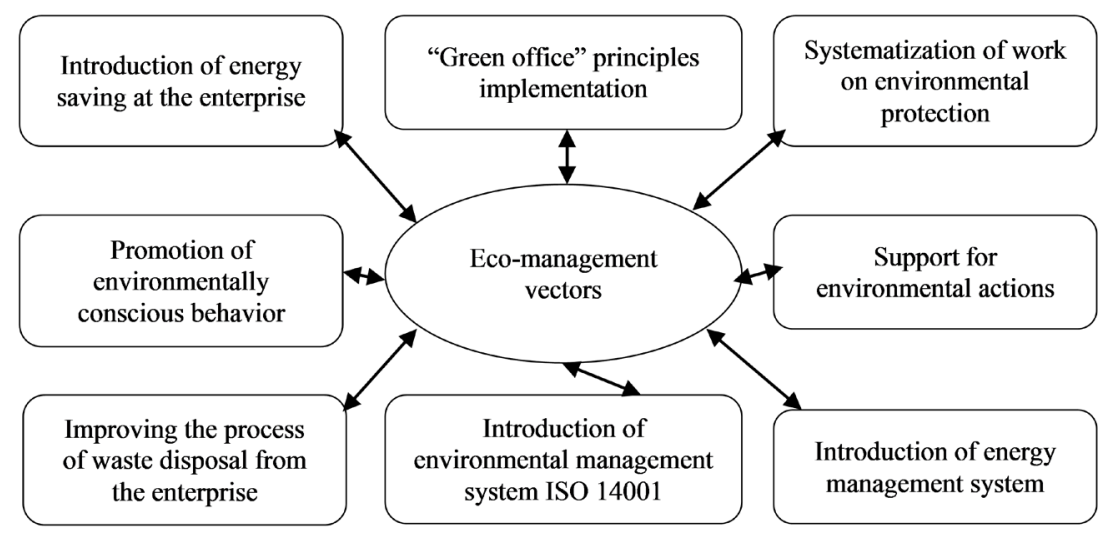

Fig. 6. Recommended eco-management vectors for companies.

Eco-management at the local level, at the enterprise level, involves the creation of a management system that should develop and implement a set of measures for rational waste-free use of resources, reducing the use of fuel and energy resources, environmentally friendly products and waste processing.

Most companies in the development of corporate social responsibility also lay down provisions on the environmental attitude to work, production, consumer, resources. Many corporations have their own recycling plants that provide reuse of raw materials. In offices, as well as in residential buildings, waste and garbage are sorted according to the possibility of their reuse or recycling. Also, each European company carries out special marking on its manufactured products in accordance with the ISO standard, which allows the consumer to determine to which type the products of this company belong. 
The formation of the environmental management system takes place in a spiral: starting with the development, approval of programs and ending with the public declaration of the developed environmental policy and goals. As a basic principle, environmental policy should include the consistent improvement and prevention of negative effects on the environment. The subsequent sequence of interrelated actions in the environmental management system includes planning, organization and practical implementation, internal monitoring and control of activities carried out in accordance with the adopted policy. An obligatory part of any environmental management system is an audit (independent evaluation of the results achieved), periodic analysis and review of the management system. It is obvious that the absence or insufficient development of any stage of activity makes the whole system of environmental management inefficient.

The success of an environmental management system depends on the commitments made at all levels. Examining the level of the enterprise, we note that the system of ecomanagement allows the company to ensure compliance with its goals in the field of environmental protection of the region and demonstrate this to a wide range of stakeholders, which include: state environmental control; the population living in the zone of influence; consumers of products; owners; investors; insurance companies; suppliers and partners; staff of the organization; environmental community; mass media.

Environmental management is able to play an exceptional role in solving environmental problems in the exit of the regions of Ukraine from the socio-economic crisis, with a critical limitation of available financial and material resources. This conceptual vision of environmental activities, based on the ecological criteria of economic development of regions, seems promising, both at the level of methodology of economic theory and the national economic system, the global economy.

The introduction of environmental standards at the enterprise makes it possible to prevent the negative impact of economic activity on the environment, to combine direct production activities with environmental protection. The advantages that demonstrate the economic usefulness and feasibility of implementing an environmental management system and the adoption of standards in the enterprise include: increasing the competitiveness of the enterprise in domestic and foreign markets, the ability to develop new markets, including "green" light to EU markets. is even more important because of the political orientation of our country; gaining a positive image of the enterprise; training and hiring more qualified staff; improving product quality and attracting new customers, as in the minds of consumers product quality will be associated with its compliance with environmental standards; saving production costs and resources, rationalization of consumption of materials and raw materials, water, energy; reducing the risk of emergencies and the scale of their consequences; reduction of environmental payments and more effective compliance with the law, avoidance of fines and penalties by reducing emissions of harmful substances; improvement of relations with partners, investors, public authorities, which is manifested in the reduction of administrative pressure on the company by regulatory authorities through declarations, as well as the ability to obtain state support (lower interest rates on loans; lower interest rates on environmental insurance).

In order to implement eco-management at Ukrainian enterprises, it is necessary to adapt the world experience in environmental management and to implement mechanisms and tools from the already existing standards of eco-management and audit. Unfortunately, Ukrainian enterprises do not yet understand the importance of rational use of resources and protection of the environment. Moreover, only large enterprises assess the impact of their own waste and try to dispose of some, and small and medium-sized enterprises do not pay as much attention to environmental management. The reasons for this are their lack of understanding of the degree of their impact on the environment and the benefits that can be gained from the implementation of innovative environmental developments. However, 
European experience shows that every European is willing to pay a higher price for an environmentally friendly product than for a regular one. Accordingly, entrepreneurs who understand this, get the maximum profits, become competitive not only in national but also in global markets, form a positive image.

Implementation of eco-management on three levels will allow the country to promote socio-economic development of regions, improve the health and life of the population, as well as enable companies to develop and implement new innovations in the field of ecomanagement. The implementation of environmental management will promote the socioeconomic development of regions, improve the health and life of the population, as well as enable companies to develop and implement new innovations in the field of environmental management through the introduction of anti-corruption audit tools.

\section{Conclusions}

Internal control system testing and applying sampling method are an initial steps of anticorruption audit doing. The approach to sampling creation should be based on auditor professional judgment, that is the main element of the anti-corruption audit as it depends on business awareness which determines potential business risk spheres.

The auditors may offer safeguards by implementing actions that minimize the causes and conditions of fraud, when they identify fraud facts. The ways to minimize the causes of fraud are to create in the company the atmosphere of social importance for each employee, material interest.

Therefore, based on the above, anti-corruption audit is an imperative for effective environmental management. The strategic goal of anti-corruption policy in the context of digitalization is to combat corruption at all levels by increasing the transparency of state bodies, respecting human and civil rights and freedoms, creating conditions for economic development, ensuring European social standards and welfare, reducing corruption in Ukraine and eliminating the causes and the conditions that determine it. Today, the digital segment of the economy is given superficial attention, which creates the preconditions for the development of corruption in this segment. The existing basic changes in the legal anticorruption mechanism in Ukraine have laid the foundation for further improvement of the system and require access to a new level of doing business - digital.

\section{References}

1. Ayub, K. (2019). Innovative models of functioning of anti-corruption bodies in the world. Aspects of public administration, (11), 79-84.

2. Babyak, N., Bilotska, I., \& Starushyk, Yu. (2015). Anticorruption compliance: basic principles and prospects for implementation in the domestic corporate sector. State and Regions. Series: Economics and Entrepreneurship, (4), 3-9.

3. Gnylytska, L. (2017). Anti-corruption audit as a means of combating corporate fraud. Independent auditor, (20), 8-14.

4. Grishchuk, M. (2019). Theoretical and legal content of the genesis of anti-corruption legislation in Ukraine. Actual problems of jurisprudence, (4), 269-275.

5. Dyka, O., \& Naumchuk, K. (2019). Social aspect of corruption development in the process of development of state anti-corruption policy. Investments: practice and experience, (22), 107-111.

6. Zarembsky, Yu. (2019). Anticorruption policy of the state: administrative and legal aspect. Actual problems of jurisprudence, (4), 276-281. 
7. Marchenko, A. (2020). Evolution of the system of anti-corruption bodies in Ukraine: from counteraction to prevention. Collection of scientific works of the National Academy of Public Administration under the President of Ukraine, (2), 70-79.

8. Naumchuk, K. (2020). Features of formation and implementation of state anticorruption policy. Investments: practice and experience, (4), 134-138.

9. Parkhomenko-Kutsevil, O. (2019). Anticorruption culture as a basis for the formation of effective mechanisms for preventing corruption. Theory and practice of public administration, (2), 25-30.

10. Rostovska, K. (2018). International experience of creation and functioning of anticorruption courts in the world. Visnyk of Kharkiv National University named after V. Karazin. Series: Right, (25), 87-89.

11. Sobakar, A. (2020). Application of anti-corruption tools in the activities of public administration entities: foreign experience and prospects of its borrowing for Ukraine. Scientific herald of the Dnipropetrovsk State University of Internal Affairs, (1), 68-74.

12. Timofeev, S. (2019). The place of anti-corruption culture in the process of preventing corruption in Ukraine. Public administration and regional development, (6), 956-978.

13. Fidrya, Y. (2017). Problems of legislative regulation of the prohibition of receiving gifts by persons covered by anti-corruption legislation. Historical and Legal Journal, (2), 135-139.

14. Chizhevskaya, L., Koretskaya, Yu., \& Palamarchuk, A. (2019). Transparency of financial statements prepared in accordance with IFRS as an instrument of anticorruption activities in Ukraine. Problems of theory and methodology of accounting, control and analysis, (1), 110-115.

15. Shcherbak, M. (2020). Legal aspect of formation and implementation of anti-corruption policy in Ukraine taking into account the experience of foreign countries. Legal Journal of Donbass, (3), 155-161.

16. Mizik, Y. (2019). Anticorruption audit. Kharkiv: KhNUMG.

17. Fadeeva, A., \& Sazhina S. (2018). Anti-corruption audit as a mechanism for combating corruption. Young Scientist, (15), 41-43.

18. Slobodyanyk, Yu., Matienko-Zubenko, I., Marynich, I., \& Syrotenko, N. (2020). State audit as a modern tool for preventing corruption. Financial and credit activities: problems of theory and practice, (3), 158-166.

19. Shkarovsky, D. (2019). Fighting Corporate Fraud: Tender or Necessity. Law Gazette, (11), 23-30.

20. Nazarova, K., Mysiuk, V., Gordopolov, V., Koval, V., \& Danilevičienè, I. (2020). Preventional audit: implementation of SOX control to prevent fraud. Business: Theory and Practice, 21(1), 293-301. https://doi.org/10.3846/btp.2020.11647.

21. Nazarova, K., Hordopolov, V., Kopotiienko, T., Miniailo, V., Koval, V., \& Diachenko, Y. (2019). Audit in the state economic security system. Management Theory and Studies for Rural Business and Infrastructure Development, 41(3), 419-430.

22. Nazarova, K., Nezhyva, M., Lositska, T., Miniailo, V., \& Novikova N. (2020). Forensic-audit as an imperative of economic security and development of the company in the conditions of global transformations. Financial and credit activity: problems of theory and practice, (4), 99-106. https://doi.org/10.18371/fcaptp.v4i35.221808

23. Nazarova, K., Hordopolov, V., Zaremba, O., \& Nezhyva, M. (2019). Analytical procedures of auditing within the framework of raising standards for its quality control. 
Financial and credit activity: problems of theory and practice, (30), 128-135. https://doi.org/10.18371/fcaptp.v3i30.179523

24. Parkhomenko-Kutsevil, O. (2019). Formation and development of modern anticorruption bodies of state power as a basis for preventing and overcoming corruption: theoretical and methodological analysis (Kyiv: SE "Publishing House "Personnel").

25. Nieuwlands, P. (2018). IIA Fighting Corruption: What Should Internal Auditors Do? https://ic.globaliia.org/Documents/CS-3-5.pdf.

26. Tillipman, J. (2000). The Foreign Corrupt Practices Act \& Government Contractors: Compliance Trends \& Collateral Consequences (GW Law Faculty Publications \& Other Works. Dinah Shelton ed.).

27. Golovkina, B. (2019). Prevention of corruption. Kharkiv: Pravo.

28. Gnilitskiy, L. (2016). Anti-corruption audit in management risk corporate fraud. https://ir.kneu.edu.ua

29. Fadeeva, A. A., \& Sazhin, S. S. (2018). Anti-corruption audit as a mechanism of struggle against corruption. The Young scientist, (15), 41-43.

30. Novikov, A. V. (2020). The anti-corruption compliance in the activities of Ukrainian companies as one of the mechanisms of prevention of corruption. https://www.kmu.gov.ua/en/news/uryad-priznachiv-oleksandra-novikova-golovoyunacionalnogo-agentstva-z-pitan-zapobigannya-korupciyi.

31. Bui, B., \& Villiers, C. (2021). Recovery from Covid-19 towards a low-carbon economy: a role for accounting technologies in designing, implementing and assessing stimulus packages. American Journal of Agricultural Economics. https://doi.org/10.1111/acfi.12746.

32. Vertakova, Yu., \& Plotnikov, V. (2017). Problems of sustainable development worldwide and public policies for green economy. Economic annals-XXI, (166), 4-11.

33. Mohring, N., Bozzola, M., Hirsch, S., \& Finger, R. (2020). Are pesticides risk decreasing? The relevance of pesticide indicator choice in empirical analysis. Agricultural Economics. https://doi.org/10.1111/agec.12563.

34. Pavlyk, V. (2020). Assessment of green investment impact on the energy efficiency gap of the national economy. Financial markets, institutions and risks, (4), 117-123.

35. Shkuropat, A., \& Stepanov, V. (2019). Methodological approaches for inclusion of factors of a "green economy" into medium term forecasting models for regional development. Ekonomichni Innovatsii, (4), 199-210.

36. Karpenko, O., Turenko, L., \& Karpenko, H. (2018). Modern tools for the ensuring the eco development of the national model of the "green" economy. Ekonomichni Innovatsii, (4), 78-90.

37. Potapenko, V., Khlobystov, Y., \& Kornatowski, R. (2017). Green modernization of Ukraine's economy: analysis of barriers and drivers based on interviewing of the companies. Environmental economics, (2), 50-56.

38. PwC. (2018). Fraud in Ukrainian companies. https://www.consultancy.eu

39. National Anti-Corruption Agency (2020). https://nabu.gov.ua/en/tags/national-agencycorruption-prevention

40. Law of Ukraine (2014). On prevention of corruption: the Law of Ukraine dated 14.10.2014 № 1700-VII (2014). https://zakon.rada.gov.ua/laws/show/1700-18

41. UNODC. (2021). Guidelines for the development and implementation of measures to prevent and combat corruption. https://www.unodc.org/unodc/index.html 
42. Law of Ukraine (2017). The decision of the National Agency for prevention of corruption № 75 of 02.03.2017 "On approval of model anti-corruption program of legal entities". http://www.minregion.gov.ua

43. Asters (2019). Model anti-corruption program of legal entities. https://www.asterslaw.com

44. EPI (2020). Environmental Performance Index. 2020 EPI Results. https://epi.yale.edu/epi-results/2020/component/epi 